\title{
Root Endophytic Fungi: Research Update
}

\author{
Neha Chadha, Manjita Mishra, Ram Prasad \\ Amity Institute of Microbial Technology \\ Amity University of Uttar Pradesh, Sector 125, Noida- 201303, India
}

\author{
Ajit Varma (Corresponding author) \\ Amity Institute of Microbial Technology \\ Amity University of Uttar Pradesh, Sector 125, Noida- 201303, India \\ Tel: 91-981-089-9562Ｅ-mail: ajitvarma@amity.edu
}

Received: May 23, 2014 Accepted: June 5, 2014

doi:10.5296/jbls.v5i2.5960ＵRL: http://dx.doi.org/10.5296/jbls.v5i2.5960

\begin{abstract}
Fungal endophytes are group of microorganisms that reside asymptomatically within the healthy living tissue. Root endophytic fungi like dark septate endophytes (DSE), Piriformospora indica and Trichoderma show mutualistic association with many plant species. The endophytes are known to produce a diverse group of secondary metabolites, extracellular enzymes, antibiotics, antifungal, anticancer agents that can be used as therapeutic drugs, agrochemicals or in industries. Plants associated with fungal endophytes play an important role in the survival of plants in extreme stressed condition. This review focuses on the functions of fungal root endophytes, their relationship with host plant, tolerance to abiotic stress and secondary metabolites production against various pathogens.
\end{abstract}

Keywords: Fungal Endophytes, Plant Growth Promoting Fungus, Secondary Metabolites, Pirifrmospora indica, Dark Septate Endophyte, Arbuscular Mycorrhizal (AM)

\section{Introduction}

The term endophyte was coined by the German phytopathologist Heinrich Anton De Bary in 1884 , and is used to define fungi or bacteria occurring inside plant tissues without showing disease in the host plant (Wilson 1995). In contrast to others like epiphytes and mycorrhiza, endophytes reside within leaves, bark, stems and roots of the plant whereas mycorrhiza only colonizes the roots of the host plant (Saikkonen et al. 1998). Root endophytes harbor an 
important component of microbial community that is different from above ground plant tissue (Addy et al. 2005), but as common as mycorrhizal fungi that reside below the ground (Weishampel and Bedford 2006). They differ from mycorrhizal fungi in morphology, development and nutrient transfer (Brundrett 2004). Brundrett and Kendrick (1988) stated that endophytic fungi living in the old roots as Glomerocycete can service for more than years even after the collapse of arbuscules. Fungal endophytes are the microorganisms that reside inside the plant tissue that can be roots, leaves or stem. They basically fall in ascomycota and basidiomycota groups (Arnold and Lutzoni 2007; Selosse et al. 2009). Endophytic fungi are plant mutualists and show various benefits to the host plant, for example abiotic stress tolerance (Redman et al. 2002), resistance to pathogens and disease (Benhamou and Garand 2001) and the production of secondary metabolites (Schulz et al. 1995). There are more than one million species of endophytic fungi associated with plants worldwide that can provide a variety of secondary bioactive products such as alkaloid, benzopyranones, flavanoids, phenols, phytochemicals and anticancer agents (Aly et al. 2010; Kharwar et al. 2011; Kusari and Spiteller 2012b). Endophytic fungi promote plant growth through auxin (IAA) (Zou and Tan 1999), phosphate solubilization (Malla et al. 2004; Wakelin et al. 2004) and siderophore production (Costa and Loper 1994).

Fungal root endophytes involve diverse group of fungi. Some specific examples are Dark septate endophytes (DSE), Trichoderma, Piriformospora indica, that are known to be true root endophytes. This review focuses on the functions of fungal root endophytes, their relationship with host plant, and secondary metabolites production against various pathogens.

\subsection{Dark Septate Endophyte}

Dark septate endophyte (DSE) is a ubiquitous group of ascomycete's fungi that may function as saprophytes or mutualistic. Kohn and Stasovski (1990) found that these fungi can survive in cold and stressed environment than AM fungi. DSE differ from other group of fungi because of their septate and melanised hyphae (Yu et al. 2001). DSE produces conidia with microsclerotia in plant roots. It has been found that these groups of fungi uses inorganic form of nitrogen that in turn benefits the host plant for nutrient uptake (Upson et al. 2009; Newsham 2011). They are frequently observed in cortex, epidermis as well on root surface. Sieve elements of roots of Atriplex canescens were predominately colonized with the hyaline hyphae and non-pigmented fungal structure (Barrow and Aaltonen 2001). They have been reported from many plants and habitat worldwide. Phialocephala fortinii (Wang and Wilcox 1985) has a broad host and geographical range (Ahlick and Sieber 1996) mostly dominated in Europe and western Canada. Phialocephala dimorphospora, Phialocephala fortinii, Phialocephala finlandia forms association with the root of alpine ericoid. Colonization by this fungus has a unique characteristic; hence they are sometimes termed as ericoid mycorrhizae. Other than ericoid host's $P$. fortinii and mycelium radices atrovirens (MRA) also colonizes the roots of Fagus sylvatica, Pinus sylvestris, Phialocephala resinosa, Phialocephala contorta and various alpine perennials (Ahlick and Sieber 1996). Colonization of roots with dark septate endophyte increases the growth of the plant (Read and Haselwandter 1981).

\subsection{Trichoderma Species}




\section{Macrothink}

Journal of Biology and Life Science ISSN 2157-6076 2014, Vol. 5, No. 2

Trichoderma species is considered as a major component of soil biodiversity that is mostly associated with plant roots. However, recent studies have revealed that Trichoderma species is not only associated with plant roots but they also persist above ground tissues (Evans et al. 2003; Bailey et al. 2006). Trichoderma species has been widely used as a biocontrol agent against soil borne pathogens (Whipps 2001). Various toxic compounds (e.g., the antibiotics gliotoxin, gliovirin) and extracellular enzymes are released by Trichoderma species to kill fungal pathogen that penetrate and utilize host nutrients (Lorito et al. 1996). Interaction of arbuscular mycorrhiza with Trichoderma shows synergistic effect on plant growth through a wide range mechanism. The use of Trichoderma species as biotrophic decomposer and as endophyte makes it an important tool for agricultural and natural ecosystems (Harman et al. 2004). Some Trichoderma isolates enhances plant growth and reduce damage against nematode damage (Meyer et al. 2001). The genus Trichoderma produces a wide range of metabolites, plant growth regulators (ciclonerodiol), antibiotics (anthraquinone), antifungal (phenolic compounds), antitumor agents and immune modulatory compounds (harzianodiona) that expand the use of this organism commercially (Supothina et al. 2007, Xiao-Yan et al. 2006).

\subsection{Piriformospora Species}

Piriformospora spp. (Verma et al. 1998) is a root endophytic fungus discovered from Thar Desert of India, belongs to family basidiomycetes (Verma et al. 1999; Pham et al. 2004) that colonize the root cortex of many plant species. Like Arbuscular mycorrhizal fungi, Piriformospora indica and Sebacina vermifera, (Basidiomycota, Sebacinales) has a broad spectrum against soil born fungal pathogens, promotes plant growth and induces resistance against various insects/pests (Varma et al. 2013).

Basiewicz et al. (2012) have described a new species of Piriformospora williamsii and have established its phylogenetic relationship with other members of Sebacinales. Recent study reported $25 \mathrm{Mb}$ genome of $P$. indica (Zuccaro et al. 2009, 2011). The main features of $P$. indica genome sequence include $50.68 \%$ GC content, $4.68 \%$ repeat rate, 11,769 protein-coding genes, 5.16 average exons per gene, gene density of 471(number of gene per $\mathrm{Mb}$ ), 867 secreted proteins, 386 small secreted proteins (SSP), 3,134 unique gene models, 197 unique SSP and 58 tRNA genes. This breakthrough research is the first in-depth genomic study that describes a mutualistic symbiont with a biphasic lifestyle through extensive comparative analysis of the $P$. indica genome with other Basidiomycota and Ascomycota fungi that have diverse lifestyle strategies identified features typically associated with both, biotrophism and saprotrophism. The tightly controlled expression of the lifestyle- associated gene that sets during the onset of the symbiosis was revealed by microarray analysis that argues for a biphasic root colonisation strategy of $P$. indica.

This root interacting fungus forms asexual chlamydospores and can easily be grown on various medium (Pham et al. 2004; Prasad et al. 2005). The chlamydospores occur as typical pyriform. $P$. indica readily colonizes the Arabidopsis thaliana and increases the yield and salt tolerance in barley plant (Oelmüller et al. 2009; Varma et al. 2013). The fungus uses unidentified signaling pathway to protect its host from pathogen and induces systemic resistance (Waller et 
al. 2005; Serfling et al. 2007). Plants infected with $P$. indica results in higher yield, early flowering and seed production and increase fresh weight (Varma et al. 2013; Prasad et al. 2013). Tolerance to abiotic stress was induced in Arabidopsis thaliana; overall growth and biomass production was achieved in herbaceous mono- and dicots, medicinal plants, and other important crops (Verma et al. 1999).

\section{Functions of Fungal Root Endophytes}

\subsection{Plant Growth Promoting Properties}

From the past few decades' agrochemicals are been used by producers for crop protection, use of this has led to negative impact on crop yield as it increases the resistance of pathogen to antimicrobial agents (Gerhardson 2002). Presently, biological agents are more popular than chemical pesticides; in this concern plant growth promoting activity of root endophytic fungi has the capacity to develop sustainable systems in plant growth (Shoebitz et al. 2009). Plant growth promoting endophytes stimulate growth of plants by solublization of nutrients, production of growth regulating hormones, siderophore, antibiotics, chitinase and cyanide (Pal et al. 2001).

Crop productivity is mainly affected by different stress factors for e.g. high alkaline soil contains high amount of ions that reduces the nitrogen fixation. These adverse conditions reduce the water absorption by plants and induce metabolic changes and decrease the growth rate (Joseph et al. 2007). In such type of soil use of endophytic fungi plays a major role as stress-tolerating organisms. Root endophytic PGPF are those that reside in the roots of the host plants and are beneficial for its host. (Table2,3). PGPF are crop specific and their significance on plant is limited because of variation in climate and soil inconsistency (Khalid et al. 2004, $\mathrm{Wu}$ et al. 2005). Plant growth promoting traits of endophytic fungi are phosphate solubilisation; IAA production for e.g. Trichoderma virens produces the auxin related compounds and increases the growth and development of A. thaliana (Cornejo et al. 2009), ammonia and salicylic production, siderophore, HCN production and tolerance to heavy metals. Other factors are also responsible for its effect on PGPF activities i.e., soil type, nutrient, moisture content and organic matter (De Freitas and Germida 1992).

PGPF has been used as biocontrol agent as it cooperatively decreases the pest and pathogens and it is one of the biological and effective approaches to control soil pathogens (Ramamoorthy et al. 2001).

Table 2. Functions of root endophytic fungi on growth of the plant

\begin{tabular}{|l|l|l|l|}
\hline Fungi & Host & Effect on plant & Reference \\
\hline Cryptosporiopsis spp & Larix decidua & Increased root length & Schulz et al. 2002 \\
\hline $\begin{array}{l}\text { Periconia } \\
\text { macrospinosa }\end{array}$ & Brassica compestris & Increased root growth & Shin et al. 2005 \\
\hline Phialocephala fortinii & Rhododendron spp & $\begin{array}{l}\text { Increased root biomass } \\
\text { phosphorus intake }\end{array}$ & Vohnik et al. 2005 \\
\hline
\end{tabular}




\begin{tabular}{|l|l|l|l|}
\hline Piriformospora indica & $\begin{array}{l}\text { Zea mays, Nicotiana tobaccum, } \\
\text { Bacopa monniera, Artemisia } \\
\text { annua }\end{array}$ & $\begin{array}{l}\text { Increased growth and } \\
\text { early rooting in } \\
\text { tobacco calli }\end{array}$ & $\begin{array}{l}\text { Varma et al. 1999; } \\
2012\end{array}$ \\
$\begin{array}{l}\text { Spilanthes calva, Withania } \\
\text { somnifera }\end{array}$ & $\begin{array}{l}\text { Increased overall } \\
\text { growth and yield, } \\
\text { number of flowers and } \\
\text { fruits }\end{array}$ & Rai et al. 2001 \\
\hline
\end{tabular}

Table 3. Functions of root endophytic fungi in host resistance to pathogens

\begin{tabular}{|c|c|c|c|c|}
\hline Fungi & Host & Pathogen & Effect on host & Reference \\
\hline $\begin{array}{l}\text { Piriformospora } \\
\text { indica }\end{array}$ & Orzya sativa & $\begin{array}{l}\text { Fusarium } \\
\text { culmorum, } \\
\text { Cochliobolus } \\
\text { sativus }\end{array}$ & $\begin{array}{l}\text { Significant improvement in } \\
\text { biomass in infected plants }\end{array}$ & $\begin{array}{l}\text { Waller et al. } \\
2005\end{array}$ \\
\hline $\begin{array}{l}\text { DSE } \quad \text { taxon } \\
\text { LtVb3 }\end{array}$ & $\begin{array}{l}\text { Brassica } \\
\text { campestris }\end{array}$ & $\begin{array}{l}\text { Verticillium } \\
\text { longisporum }\end{array}$ & Symptoms reduced by $90 \%$ & $\begin{array}{l}\text { Narisawa et al. } \\
2004\end{array}$ \\
\hline $\begin{array}{l}\text { Phialocephala } \\
\text { fortinii }\end{array}$ & $\begin{array}{l}\text { Solanum } \\
\text { melongena }\end{array}$ & Verticillium dahliae & $\begin{array}{l}\text { Decreased symptoms of } \\
\text { pathogen }\end{array}$ & $\begin{array}{l}\text { Narisawa et al. } \\
2004\end{array}$ \\
\hline $\begin{array}{l}\text { Fusarium } \\
\text { oxysporum }\end{array}$ & $\begin{array}{l}\text { Lycopersicum } \\
\text { esculentum }\end{array}$ & $\begin{array}{l}\text { Meliodogyne } \\
\text { incognita }\end{array}$ & $\begin{array}{l}\text { Reduced infection through } \\
\text { release of antimicrobial } \\
\text { compounds by } 60 \%\end{array}$ & $\begin{array}{l}\text { Hallman and } \\
\text { Sikora } \\
1994,1996\end{array}$ \\
\hline $\begin{array}{l}\text { Acremonium } \\
\text { strictum }\end{array}$ & $\begin{array}{l}\text { Lycopersicum } \\
\text { esculentum }\end{array}$ & $\begin{array}{l}\text { Helicoverpa } \\
\text { armigera }\end{array}$ & $\begin{array}{l}\text { Decreased development of } \\
\text { pupae and larva }\end{array}$ & $\begin{array}{l}\text { Jallow et al. } \\
2004\end{array}$ \\
\hline $\begin{array}{l}\text { Acremonium } \\
\text { alternatum }\end{array}$ & $\begin{array}{l}\text { Brassica oleracia } \\
\text { var. gemmifera }\end{array}$ & Plutella xlostlla & $\begin{array}{l}\text { Decreased growth rate of } \\
\text { larva }\end{array}$ & $\begin{array}{l}\text { Raps and Vidal } \\
1998\end{array}$ \\
\hline
\end{tabular}

\subsection{Mechanism to Control Phytopathogens}

\subsubsection{Siderophore Production}

Iron is a crucial element for microbial growth and mostly it is unavailable to microbes because inorganic iron is extremely insoluble and less in concentration in soil. For iron sequestration many microbes releases the iron binding low molecular weight substances called as siderophores, which has the ability to bind with $\mathrm{Fe}^{3+}$. This bound iron become soluble and transport into the microbial cell and increase its growth (Saharan and Nehra 2011).

\subsubsection{Enzyme Production}

Hydrolytic enzymes secreted by endophytes can lyse the cell wall of fungal pathogens but not the plant cell wall, and by this it prevents the attack of phytopathogens. Host plants which colonized by endophytes have more vigour because of secretion of phytohormones i.e., cytokines, auxins (Robinson et al. 1998) and help in the absorption of minerals like nitrogen (Lyons et al. 1990) and phosphorus (Malinowski et al. 1999).

\subsection{Abiotic Stress Tolerance}


Agriculture is mostly prone to abiotic and biotic stresses, crop yield gets adversely affected as the stress condition increases either due to natural or anthropogenic factors and it may become one of the reasons for productivity limitation. Unfavourable condition like high temperature; elevated $\mathrm{CO}_{2}$, droughts, extreme rainfall, floods, cold waves, global warming etc. cause a negative impact on crops and results in economic losses.

Many genes are involved for adaptation of microbes in stressed environmental conditions (Srivastava et al. 2008). Under extreme environmental condition many microbe posses' different mechanisms i.e., metabolic process like involvement of enzymatic activities and membrane stability at high temperature and salinity (Madigen 1999). In tropical and sub tropical areas the major problem is high soil temperature for crop production and fungal colonization. Response of all the organisms is by induction of synthesis of specific proteins known as heat shock proteins (HSPs). These HSPs are composed of chaperons (such as GroEL, DnaK, DnaJ, GroES, ClpB, ClpA, ClpX,) and small form of heat shock proteins (HSPs and proteases). The role of chaperons is proper folding and alignment of denatured proteins and proteases that are useful in degradation of irreversible damaged proteins (Munchbach et al. 1999). This has been proved that microbes play a significant role in plant protection by stress management mechanisms; unique properties of stress tolerance, ubiquity, and genetic diversity and now new methods are been employed for their deployment in agriculture. Many reports are also there for AM symbiosis, which improve the plant resistance in drought condition by alteration of plant physiology and metabolic activities, expression of genes (Ruiz-Lozano and Azcon 2000) and dehydration tolerance (Allen and Boosalis1983).

$\mathrm{Wu}$ and Xia (2006) demonstrated that induction of Glomus versiforme enhanced the osmotic adjustment in citrus plants under drought condition by increasing the concentration of non-structural carbohydrates, $\mathrm{Ca}, \mathrm{Mg}$ and $\mathrm{K}$. Under water deficient condition ascorbate and glutathione plays an important role in protection and maintenance of metabolic functions of plants but low concentration of these compounds present in lavender plants shows more drought tolerant. This is because the roots of plant are colonized by Glomus sp. strain (Marulanda et al. 2007). Neto and co workers (2006) reported that A. trifolium plants inoculated with endophytic fungi showed better tolerance to flood by maintenance of osmotic pressure and proline concentration in plant tissues.

One of the examples of endophytic fungus is $P$. indica that confers the drought tolerance in $A$. thaliana by priming the expression of stress related genes. In arid and semi arid regions soil salinization is a major problem and it is increasing steadily in various part of world (Giri et al. 2003; Al-Karaki 2006). In natural environmental condition plant are colonized by both external and internal endophytic fungi and they are beneficial fungi helpful in improving plant growth and tolerance under stressed condition (Creus et al. 1998). Most of the AM fungi are incorporated with roots of $80 \%$ plants. AMF and endophytic fungi naturally occur in saline areas (Hilderbrandt et al. 2001; Yamato et al. 2008), and the most predominant occurrence of Glomus species i.e., were Glomus intraradices, G. versiform and G. etunicatum in severe saline soil of Tabriz plains having electrical conductivity of $162 \mathrm{dS} \mathrm{m}^{-1}$.

The harmful impact of salinity is not on the host plants but also on endophytic fungi; it can alter 


\section{MlMacrothink}

Journal of Biology and Life Science

ISSN 2157-6076

2014, Vol. 5, No. 2

the colonization capacity, growth of hyphae and germination of spores of fungi. Many reports are there on the effect of salinity on fungi (Jahromi et al. 2008). Percentage of root colonization by fungi decreases as the concentration of $\mathrm{NaCl}$ increases in soil (Giri et al. 2007; Sheng et al. 2008) indicating salinity inhibits the fungi colonization and arbuscular mycorrhiza formation (Sheng et al. 2008). Juniper and Abbott (2006) showed that spore germination of fungi is delayed rather than prevented. In synthetic media, the number of spores' produced by Glomus intraradices decreases as the medium contains the different concentration of salts. This reduction suggests that if salinity continuous there can be decline in colonization percentage by reducing the capacity of inoculums (spores). Abiotic stress results into series of physiological, morphological, molecular and biochemical changes in plants and adversely growth and productivity.

Mainly clavicipitaceous endophytic fungi colonize the tissues and provide the beneficial effects on host plants by increasing the resistance to pathogens and stressed conditions (Kuldau and Bacon 2008). Habitat specific adaptation also supported by F. culmorum, C. protuberate and $C$. magna endophytes. F. culmorum confers salt but not heat or disease tolerance; $C$. protuberata confers heat but not disease or salt tolerance; and $C$. magna confers disease but not heat or salt tolerance (Rodriguez et al. 2008). For e.g. in the geothermal soils of Yellowstone National Park, Dichanthelium lanuginosum plant is heavily colonized by one of the dominant endophyte i.e. Curvularia protuberate. This endophyte confers the heat tolerance to the host plant and when they are separated from one another none of them survive alone when exposed to temperature $>38^{\circ} \mathrm{C}$ (Redman et al. 2002). These endophytes symbiotically tolerates the stress conform the evolutionary dynamics plays differently in various habitats and confer the stress tolerance to plants (Table 4).

Table 4. Some examples of fungal endophytes that conferred abiotic stress tolerance

\begin{tabular}{|c|c|c|c|}
\hline Fungal endophytes & Abiotic stress & Host Plants & Refrences \\
\hline Neotyphodium spp & Drought & $\begin{array}{l}\text { Festuca pratensis, Perennial Ryegrass, } \\
\text { Festuca arizonica }\end{array}$ & $\begin{array}{l}\text { Malinowski et al. } 1997 \\
\text { Barker et al. } 1997 \\
\text { Morse et al. } 2002\end{array}$ \\
\hline Curvularia protuberate & Heat & Dichanthelium lanuginosum & Redman et al. 2002 \\
\hline $\begin{array}{l}\text { Curvularia protuberate } \\
(C p 4666 D)\end{array}$ & Drought & Dichanthelium lanuginosum & Rodriguez et al. 2008 \\
\hline Curvularia spp & Heat/Drought & Lycopersicum esculentum & $\begin{array}{l}\text { Rodriguez and Redman } \\
2008\end{array}$ \\
\hline $\begin{array}{l}\text { Fusarium } \quad \text { culmorum } \\
(\text { Fcl })\end{array}$ & Drought & $\begin{array}{l}\text { Leymus mollis, Oryza sativa, } \\
\text { Lycopersicum, esculentum }\end{array}$ & Rodriguez et al. 2008 \\
\hline $\begin{array}{l}\text { Fusarium } \quad \text { culmorum } \\
\text { (FcRed1) }\end{array}$ & Salinity & $\begin{array}{l}\text { Leymus mollis, Oryza sativa, } \\
\text { Lycopersicum } \\
\text { lanuginosum }\end{array}$ & Rodriguez et al. 2008 \\
\hline Colletotrichum spp & Drought & Lycopersicum esculentum & Rodriguez et al. 2004 \\
\hline $\begin{array}{l}\text { Fusarium spp } \\
\text { Alternaria } \mathrm{spp}\end{array}$ & Heat/Drought & Lycopersicum esculentum & $\begin{array}{l}\text { Rodriguez and Redman } \\
2008\end{array}$ \\
\hline Piriformospora indica & Salinity & Hordeum vulgare & Waller et al. 2005 \\
\hline
\end{tabular}

Previous studies documented that stress tolerance by fungal endophytes in host plant plays an important role in the survival of plants in extreme stressed condition (Rodriguez et al. 2004). 
For e.g. Class II type of endophytes confers the heat tolerance to plants in geothermal soils (Redman et al. 2002), extent of colonization by endophytes directly related to the resistance to pathogens of host plant (Arnold et al. 2003) and endophyte can confer drought tolerance to many host plants (Waller et al. 2005). Endophytes colonized plants express different range of adaptations to biotic and abiotic stress condition i.e., drought (West 1994), mineral imbalance (Malinowski et al. 1997) and soil acidity (Malinowski and Belesky 1999).

\subsection{Natural Products from Root Endophytes}

The endophytic fungi associated with the roots of the plant can produce natural active secondary metabolites that have many industrial and agriculture applications. Endophytes are known to produce various metabolites such as antibacterial, anticancer, antifungal, antiviral and immunosuppressant compounds e.g. paclitaxel, torreyanic acid, etc. which can be used in various field of medicine. Isolation and characterization of endophytic fungi for their use in medicine and industry depends upon the environmental as well as on host endophyte relationship. Since last one decade number of bioactive compounds have been isolated and characterized from root endophytic fungi, which belongs to groups like phenolics, quinones, flavonoids, terpenoids, xanthones and other biological active compound (Tan and Zou 2001; Gunatilaka 2006; Zhang et al. 2006). Various pathways like polyketide, isoprenoid, and amino acid derivation synthesize these secondary metabolites. Strobel et al. (1996) discovered that paclitaxel was produced by Pestalotiopsis microspore, isolated from Taxus wallichiana. Muscodoralbus (Strobel et al. 2001) isolated from Cinnamom zeylanicum produces an antifungal compound that has proved lethal to Aspergillus fumigates and Candida albicans (Woropong et al. 2001). Myco-diesel hydrocarbons from endophyte Gliocladium roseum can be used as an alternative source for bio-diesels (Strobel et al. 2008). Gliocladium catenulatum endophyte isolated from Theobroma cacao is used as a biocontrol agent against Crinipellis perniciosa Witches Broom disease of the Cacao tree (Rubini et al. 2005). Aspergillus fumigates isolated from twigs of the Juniperus communis, produces deoxypodophyllotoxin that has anticancer and antiviral activity. Taxol, a powerful anti cancer drug is produced by an endophyitc fungi Taxus brevifolia Nutt (Strobel et al. 1993). Endophytic fungi Pestalotiopsis microspora has been used for the isolation of antioxidant metabolites such as Pestacin and Isopestacin. Grass-associated endophyes such as Epichlo $\ddot{e}$ and Neotyphodium species have been detected with alkaloids.

A number of antifungal products are produced from endophytes. Griseofulvin was first reported from endophyte Abies holophylla that was used as an antifungal against plant pathogen. Griseofulvin and dechloro griseofulvin isolated from Xylaria species have shown high antifungal activity against Magnaporthe grisea, Puccinia recondite and Blumeria graminis f. sp. Hordei (Park et al. 2005). Endophytes are known to produce many antiviral agents. Cytonic acid A and B isolated from Cytonaema sp. act as an inhibitor for human cytomegalovirus (hCMV) protease (Jensen and Roulund 2004).

Kusari et al. (2009) demonstrated one of the examples of horizontal transfer of genes from host to endophyte. Aspergillus fumigatus fresenius was isolated from the twings of Juniperus communis L. Horstmann, which is a producer of deoxypodophyllotoxin that is known for anti 


\section{Macrothink}

Journal of Biology and Life Science ISSN 2157-6076 2014, Vol. 5, No. 2

therapeutically properties like antitumor, antiviral, and anti-inflammatory activities. Pimentel et al. (2011) reported that bioactive compounds produced by endophytes could be use in biotransformation process. Biotransformation of grandisin to tetrahydrofuran by Phomopsis species is a promising method for the production of metabolites by these endophytes. Biotransformation has also been reported from endophytic fungus isolated from Aphelandra tetragona roots (Zikmundová et al. 2002). These endophytic fungi are able to mimic mammalian metabolism through various reactions of biotransformation (Borges et al. 2007).

Table 5. List of secondary metabolites produced by fungal root endophytes

\begin{tabular}{|c|c|c|c|c|}
\hline Fungus & Source & Compound & Activity & Reference \\
\hline $\begin{array}{l}\text { Penicillium } \\
\text { expansum }\end{array}$ & $\begin{array}{l}\text { Excoecaria } \\
\text { agallocha }\end{array}$ & $\begin{array}{l}\text { Polyphenols, } \\
\text { expansols A \& B }\end{array}$ & Cytotoxic & Lu et al. 2010 \\
\hline $\begin{array}{l}\text { Curvularia } \\
\text { lunata }\end{array}$ & Niphates olemda & Cytoskyrins & $\begin{array}{l}\text { Antibacterial, anticancer } \\
\text { agent }\end{array}$ & $\begin{array}{l}\text { Brady et al. 2000, } \\
\text { Jadulco et al. } 2002\end{array}$ \\
\hline $\begin{array}{l}\text { Phoma } \\
\text { medicaginis }\end{array}$ & $\begin{array}{lr}\text { Medicago } & \text { sativa, } \\
\text { Medi- } & \text { cago } \\
\text { lupulina } & \\
\end{array}$ & Brefeldine A & Antibacterial & Weber et al. 2004b \\
\hline $\begin{array}{l}\text { Phomopsis spp } \\
\text { PSU-D15 }\end{array}$ & Garcinia dulcis & Phomoenamide & $\begin{array}{l}\text { Antimycobacterial } \\
\text { activity }\end{array}$ & $\begin{array}{l}\text { Rukachaisirikul et } \\
\text { al. } 2008\end{array}$ \\
\hline $\begin{array}{l}\text { Muscodor } \\
\text { albus }\end{array}$ & $\begin{array}{l}\text { Cinnamomum } \\
\text { zeylanicum }\end{array}$ & $\begin{array}{l}\text { Colatile organic } \\
\text { compounds }\end{array}$ & Antifungal, antibacterial & Ezra et al. 2004 \\
\hline $\begin{array}{l}\text { Pestelotiopsis } \\
\text { microspora }\end{array}$ & Taxus wallichiana & Paclitaxel & Anticancer & Strobel et al.1996 \\
\hline $\begin{array}{l}\text { Chaetomium } \\
\text { acuminata }\end{array}$ & $\begin{array}{l}\text { Edenia } \\
\text { gomezpompae }\end{array}$ & $\begin{array}{l}\text { Naphthoquinone } \\
\text { spiroketal }\end{array}$ & Allelochemical activity & $\begin{array}{l}\text { Macias- Rubalcava } \\
\text { et al. } 2008\end{array}$ \\
\hline $\begin{array}{l}\text { Muscodor } \\
\text { vitigenus }\end{array}$ & $\begin{array}{l}\text { Paullinia } \\
\text { paullinioides }\end{array}$ & Naphthalene & $\begin{array}{l}\text { Insecticides, } \\
\text { antimicrobials, } \\
\text { helminthics } \\
\text { vermicides }\end{array}$ & Strobel et al. 2007 \\
\hline
\end{tabular}

\section{Host Endophyte Relationship}

Several theories have been developed to mark the advantages of root endophyte colonization. Two of the most prominent methods are plant (Newsham 2011) and phytohormones production (Schulz and Boyle 2005). The association between host and endophyte depends upon the environmental condition and ranges from mutualistic, neutral or antagonist (Kogel et al. 2006; Moricca and Ragazzi 2008). The interaction is highly variable and transitory (Bacon and Yates 2006). Although transitory association exists; endophytic fungi are known to show various benefits to the host plant like tolerance to abiotic and biotic stress (Schulz and Boyle 2005; Rodriguez and Redman 2008). Schulz et al. (1999) demonstrated that the host endophyte interaction is a balanced antagonist that refers to a state of equilibrium between fungal virulence and plant defences. Although change can occur through an imbalance in flow of nutrients, change in environmental (Moricca and Ragazzi 2008) and stress condition (Halmschlager et al. 1993). Genetic variation plays an important role in host endophyte 
interactions. The relationship between host genotype and their lifestyle from mutualistic to parasitic has been shown by some fungal isolates (Unterseher and Schnittler 2010).

Stress tolerance to reactive oxygen species (ROS) produced by endophytes protects the host plant from drought and pathogens. ROS produced by endophytes have increased the production of antioxidant such as phenols and/or flavonoids in endophyte-infected plants. ROS denatures the cell membrane of the plant thus involving influx of nutrients that is radially absorbed by fungal hyphae (White and Torres 2010). Host specificity, selectivity and host preference also plays an important role in host endophyte relationship (Cohen 2006).Endophytic fungi interact with the roots of the plants in several ways depending upon the environment and species involved. For e.g. in tree species the interaction between the fungal root endophytes and plants takes place through the formation of mantle and hartig net. Phialocephala finlandica (C. finlandica) develops a hartig net by radial elongation that is confined till the epidermis and the mantle to the roots of yellow birch (Wilcox and Wang 1987 b). It has been reported that roots of oak and pine have been colonized with large number of root endophytic fungi (Reininger and Sieber 2012) as well as with AM fungi (Dickie et al. 2001).

\section{Conclusion}

Root endophytic fungi are the group of microorganisms that reside inside the plant roots and their association varies from mutualistic to pathogenic. Piriformospora indica has a broad spectrum of resistance against soil-borne pathogens and promotes plant growth. Endophytic fungi are excellent source of bioactive natural metabolites with broad range of functions and structural diversity therefore it can be used as a bio fertilizer. It also plays an important role in conferring resistance to biotic and abiotic stress conditions. The ease of culturing root endophytic fungi can fulfil the future demands in medical, agriculture and pharmaceutical industries.

\section{Acknowledgments}

Authors are grateful to Dr. Ashok K. Chauhan, Founder President, Amity University (Noida, India) for his encouragement and providing excellent facilities. Neha Chadha and Manjita Mishra are very thankful to DRDO, ICAR and DBT, Government of India for granting research fellowship.

\section{References}

Addy, H. D. Piercey, M. M., \& Currah, R. S. (2005). Microfungal endophytes in roots. Canadian Journal of Botany. 83.1-13. http://dx.doi.org/10.1139/b04-171

Ahlich, K., \& Sieber, T. N. (1996). The profusion of dark septate endophytic fungi in non-ectomycorrhizal fine roots of forest trees and shrubs. New phytologist. 132, 259-270. http://dx.doi.org/10.1111/j.1469-8137.1996.tb01845.x

Al-Karaki, G. N. (2006). Nursery inoculation of tomato with arbuscular mycorrhizal fungi and subsequent performance under irrigation with saline water. Scientia Horticulturae. 109, 1-7. http://dx.doi.org/10.1016/j.scienta.2006.02.019 
Allen, M. F., \& Boosalis, M. G. (1983). Effect of two species of VA mycorrhizal fungi on drought tolerance of winter wheat. New Phytologist. 93, 67-76. http://dx.doi.org/10.1111/j.1469-8137.1983.tb02693.x

Aly, A. H. Debbab, A. Kjer, J., \& Proksch, P. (2010). Fungal endophytes from higher plants: a prolific source of phytochemicals and other bioactive natural products. Fungal Diversity. 41, 1-16. http://dx.doi.org/10.1007/s13225-010-0034-4

Ananda, K., \& Sridhar, K. R. (2002). Fungal endophytes in submerged roots. In: B. Schulz, C. Boyle, T. Sieber (Eds.), Microbial Root Endophytes (pp. 179-190) Springer Berlin Heidelberg.

Apel, K., \& Hirt, H. (2004). Reactive oxygen species: metabolism, oxidative stress, and signal transduction. Annual Review of Plant Biology. 55, 373-399. http://dx.doi.org/10.1146/annurev.arplant.55.031903.141701

Arnold, A. E. Mejía, L. C. Kyllo, D. Rojas, E. I. Maynard, Z. Robbins, N., \& Herre, E. A. (2003). Fungal endophytes limit pathogen damage in a tropical tree. Proceedings of the National Academy of Sciences, USA. 100, 15649-15654. http://dx.doi.org/10.1073/pnas.2533483100

Arnold, A. E., \& Lutzoni, F. (2007). Diversity and host range of foliar fungal endophytes: are tropical trees biodiversity hot spots? Ecology. 88, 541-549. http://dx.doi.org/10.1890/05-1459

Bacon, C. W., \& White, J. F. J. (2000). Physiological adaptations in the evolution of endophytism in the Clavicipitaceae. In: C.W. Bacon \& J.F.J. White (Eds.), Microbial endophytes (pp. 237-263). New York, NY, USA: Marcel Dekker Inc.

Bacon, C. W., \& Yates, I. E. (2006). Endophytic root colonization by Fusarium species: Histology, plant interactions and toxicity. In: B. Schultz, C. Boyle, T. Sieber (Eds.), Microbial root endophytes. Berlin: Springer-Verlag. http://dx.doi.org/10.1007/3-540-33526-9_8

Bailey, B. Bae, H. Strem, M. Roberts, D. Thomas, S. Crozier, J. Samuels, G. Choi, I., \& Holmes, K. (2006). Fungal and plant gene expression during the colonization of cacao seedlings by endophytic isolates of four Trichoderma species. Planta. 224(6), 1449-1464. http://dx.doi.org/10.1007/s00425-006-0314-0

Baker, A. C. Rowan, R., \& Knowlton, N. (1997). Symbiosis ecology of two Caribbean acroporid corals. In: H.A. Lessios, \& I.G. Macintyre (Eds.), Proceedings of the 8th International Coral Reef Symposium (pp. 1295-1300). Smithsonian Tropical Research Institute, Balboa, Panama

Barker, D. J. Hume, D. E., \& Quigley, P. E. (1997). Negligible physiological responses to water deficit in endophyte-infected and uninfected perennial ryegrass. In: C.W. Bacon, \& N.S. Hill (Eds.), Neotyphodium/Grass Interactions (pp. 137-139). New York: Plenum Press

Barrow, J. R., \& Aaltonen, R. E. (2001). A method of evaluating internal colonization of Atriplex canescens (Pursh) Nutt.roots by dark septate fungi and how they are influenced by host physiological activity. Mycorrhiza. 11, 199-205. http://dx.doi.org/10.1007/s005720100111 


\section{Macrothink}

Journal of Biology and Life Science ISSN 2157-6076 2014, Vol. 5, No. 2

Basiewicz, M. Weiß, M. Kogel, K. H. Langen, G. Zorn, H., \& Zuccaro, A. (2012). Molecular and phenotypic characterization of Sebacina vermifera strains associated with orchids, and the description of Piriformospora williamsii sp. nov. Fungal Biology. 116, 204-213. http://dx.doi.org/10.1016/j.funbio.2011.11.003

Benhamou, N., \& Garand, C. (2001). Cytological analysis of defense related mechanisms induced in pea root tissues in response to colonization by nonpathogenic Fusarium oxysporum $\mathrm{F}_{0}$ 47. Phytopathology. 91, 730-740. http://dx.doi.org/10.1094/PHYTO.2001.91.8.730

Bischoff, J. F., \& White, J. F. (2005). Evolutionary development of the Clavicipitaceae. In: J. Dighton, J.F. White, P. Oudemans (Eds.), The fungal community: Its organization and role in the ecosystem (pp. 505-518). Boca Raton, FL, USA: Taylor \& Francis.

Borges, K. B. Borges, W. D. S. Pupo, M. T., \& Bonato, P. S. (2007). Endophytic fungi as models for the stereo selective biotransformation of thioridazine. Applied Microbiology and Biotechnology. 77, 669- 674. http://dx.doi.org/10.1007/s00253-007-1171-x

Brady, S. F. Wagenaar, M. M. Singh, M. P. Janso, J. E., \& Clardy, J. (2000). The cytosporones, new octaketide antibiotics isolated from an endophytic fungus. Organic Letters. 14, 4043-4046. http://dx.doi.org/10.1021/ol006680s

Brundrett, M. (2004). Diversity and classification of mycorrhizal associations. Biological Reviews. 79, 473-495. http://dx.doi.org/10.1017/S1464793103006316

Brundrett, M. C., \& Kendrick, W. B. (1988). The mycorrhizal status, root anatomy, and phenology of plants in a sugar maple forest. Canadian Journal of Botany. 66, 1153-1173. http://dx.doi.org/10.1139/b88-166

Campanile, G. Ruscelli, A., \& Luisi, N. (2007). Antagonistic activity of endophytic fungi towards Diplodia corticola assessed by in vitro and in planta tests. European Journal of Plant Pathology. 117, 237-246. http://dx.doi.org/10.1007/s10658-006-9089-1

Clay, K. (1988). Fungal endophytes of grasses: a defensive mutualism between plants and fungi. Ecology. 69, 10-16. http://dx.doi.org/10.2307/1943155

Clay, K. (1990). Fungal endophytes of grasses. Annual Review of Ecology and Systematics. 21, 275-297. http://dx.doi.org/10.1146/annurev.es.21.110190.001423

Clay, K., \& Schardl, C. L. (2002). Evolutionary origins and ecological consequences of endophyte symbiosis with grasses. American Naturalist. 160, S99-S127. http://dx.doi.org/10.1086/342161

Cohen, S. D. (2006). Host selectivity and genetic variation of Discula umbrinella isolates from two oak species: analyses of intergenic spacer region sequences of ribosomal DNA. Microbial Ecology. 52, 463-469. http://dx.doi.org/10.1007/s00248-006-9073-5

Cornejo, H. A. C. Rodrı'guez, L. M. Penagos, C. C., \& Bucio, J. L. (2009). Trichoderma virens, a Plant Beneficial Fungus, Enhances Biomass Production and Promotes Lateral Root Growth through an Auxin-Dependent Mechanism in Arabidopsis. Plant Physiology. 149, 1579-1592. 
http://dx.doi.org/10.1104/pp.108.130369

Costa, J. M., \& Loper, J. E. (1994). Characterization of siderophore production by the biological control agent Enterobacter cloacae. Molecular Plant-Microbe Interaction. 7, 440-448. http://dx.doi.org/10.1094/MPMI-7-0440

Creus, C. M. Sueldo, R. J., \& Barassi, C. A. (1998). Water relations in Azospirillum-inoculated wheat seedlings under osmotic stress. Canadian Journal of Botany. 76, 238-244. http://dx.doi.org/10.1139/b97-178

Currah, R. S. Sigler, L., \& Hambleton, S. (1987). Microbial Endophytes of Orchid Roots. In: B. Schulz, C. Boyle, T. Sieber (Eds.), Microbial Root Endophytes (pp. 153-177). Springer Berlin Heidelberg.

De Bary, H. A. (1884). Vergleichende Morphologie und Biologie der Pilze Mycetozoen und Bacterien.Verlag von Wilhelm Engelmann, Leipzig. Berlin.

De Freitas, J. R., \& Germida, J. J. (1992). Growth promotion of winter wheat by fluorescent pseudomonads growth under growth chamber conditions. Soil Biology and Biochemistry. 24, 1127-1 135. http://dx.doi.org/10.5962/bhl.title.42380

Dickie, I. A. Koide, R. T., \& Fayish, A. C. (2001). Vesicular-arbuscular mycorrhizal infection of Quercus rubra seedlings. New Phytologist. 151, 257-264. http://dx.doi.org/10.1046/j.1469-8137.2001.00148.x

Dorothy, D. A., \& Kandikere, R. S. (2009). Assemblage and diversity of fungal associated with mangrove wild legume Canavalia cathartica. Tropical and Subtropical Agroecosystems. 10, 225-235.

Evans, C. Holmes, K., \& Thomas, S. (2003). Endophytes and mycoparasites associated with an indigenous forest tree, Theobroma gileri, in Ecuador and a preliminary assessment of their potential as biocontrol agents of cocoa diseases. Mycological Progress. 2(2), 149-160. http://dx.doi.org/10.1007/s11557-006-0053-4

Ezra, D. Hess, W. M., \& Strobel, G. A. (2004). New endophytic isolates of Muscodor albus, a volatile-antibiotic-producing fungus. Microbiology. 150, 4023-4031. http://dx.doi.org/10.1099/mic.0.27334-0

Faeth, S. H. Gardner, D. R. Hayes, C. J. Jani, A. Wittlinger, S. K., \& Jones, T. A. (2006). Temporal and spatial variation in alkaloid levels in Achnatherum robustum, a native grass infected with the endophyte eotyphodium. Journal of Chemical Ecology. 32, 307-324. http://dx.doi.org/10.1007/s10886-005-9003-x

Gamboa, M. A., \& Bayman, P. (2001). Communities of endophytic fungi in leaves of a tropical timber tree (Guarea guidonia: Meliaceae). Biotropica. 33, 352-360. http://dx.doi.org/10.1111/j.1744-7429.2001.tb00187.x

Gao, K. X., \& Mendgen, K. (2006). Seed-transmitted beneficial endophytic Stagonospora sp. can penetrate the walls of the root epidermis, but does not proliferate in the cortex, of 
Phragmites australis. Canadian Journal of Botany. 84, 981-988. http://dx.doi.org/10.1139/b06-056

Gerhardson, B. (2002). Bology substitutes for pesticides. Trends Biotechnology. 20, 338-343. http://dx.doi.org/10.1016/S0167-7799(02)02021-8

Giri, C. Pengra, B. Zhu, Z. Singh, A., \& Tieszen, L. (2007). Monitoring mangrove forest dynamics of the Sundarbans in Bangladesh and India using multi-temporal satellite data from 1973-2000. Estuarine, Coastal and Shelf Science. 73, 91-100. http://dx.doi.org/10.1016/j.ecss.2006.12.019

Giri, V. Wilkinson, M., \& Gower, D. J. (2003). A new species of Gegeneophis Peters (Amphibia: Gymnophiona: Caeciliidae) from southern Maharashtra, India, with a key to the species of the genus. Zootaxa. 351, 1-10.

Gunatilaka, A. A. L. (2006). Natural products from plant-associated microorganisms: Distribution, structural diversity, bioactivity, and implications of their occurrence. Journal of Natural Products. 69, 509-526. http://dx.doi.org/10.1021/np058128n

Hallmann, J. Sikora, R. A. (1994). Influence of Fusarium oxysporum, a mutualistic fungal endophyte, on Meloidogyne incognita infection of tomato. Journal for Plant Disease and Plant Protection. 101, 475-481.

Hallmann, J., \& Sikora, R. A. (1996). Toxicity of fungal endophyte secondary metabolites to plant- parasitic nematodes and soil-borne plant-pathogenic fungi. 102, 155-162.

Halmschlager, E. Butin, H., \& Donabauer, E. (1993). Endophytic fungi in leaves and twigs of Quercus petrea. European Journal of Plant Pathology. 23, 51-63. http://dx.doi.org/10.1111/j.1439-0329.1993.tb00805.x

Harman, G. Howell, C. Viterbo, A. Chet, I., \& Lorito, M. (2004). Trichoderma speciesoportunistic, avirulent plant symbionts. Nature Reviews Microbiology. 2(1), 43 - 56. http://dx.doi.org/10.1038/nrmicro797

Herre, E. A. Bael, S. A. V. Maynard, Z. Robbins, N. Bischoff, J. Arnold, A. E. Rojas, E. Mejía, L. C. Cordero, R. A. Woodward, C., \& Kyllo, D. A. (2005). Tropical plants as chimera: some implications of foliar endophytic fungi for the study of host plant defense, physiology, and genetics. In: D.F.R.P. Burslem, M.A. Pinard, S.E. Hartley (Eds.), Biotic interactions in the tropics, Cambridge, UK (pp. 226-240). Cambridge University Press.

Hilderbrandt, U. Janetta, K. Ouziad, F. Renne, B. Nawrath, K. Bothe, H. (2001). Arbuscular mycorrhizal colonization of halophytes in Central European salt marshes. Mycorrhiza. 10. 175-183. http://dx.doi.org/10.1007/s005720000074

Iqbal, S. H. Firdaus-e-Bareen, \& Yousaf, N. (1995). Fungal endophytes in submerged roots. In: B. Schulz, C. Boyle, T. Sieber (Eds.), Microbial Root Endophytes (pp. 179-190) Springer Berlin Heidelberg.

Jadulco, R. Brauers, G. Edrada, R. A. Ebel, R. Wray, V. Sudarsono, V., \& Proksch, P. (2002). 
New metabolites from sponge- derived fungi Curvularia lunata and Cladosporium herbarum. Journal of Natural Products. 65, 730-733. http://dx.doi.org/10.1021/np010390i

Jahromi, F. Aroca, R. Porcel, R., \& Ruiz-Lozano, J. M. (2008). Influence of salinity on the in vitro development of Glomus intraradices and on the in vivo physiological and molecular responses of mycorrhizal lettuce plants. Microbial Ecology. 55, 45-53. http://dx.doi.org/10.1007/s00248-007-9249-7

Jallow, M. F. A. Dugassa-Gobena, D., \& Vidal, S. (2004). Indirect interaction between an unspecialized endophytic fungus and a polyphagous moth. Basic and Applied Ecology. 5, 183-191. http://dx.doi.org/10.1078/1439-1791-00224

Jensen, A. M. D., \& Roulund, N. (2004). Occurrence of Neotyphodium endophytes in permanent grassland with perennial ryegrass (Lolium perenne) in Denmark. Agriculture, Ecosystems and Environment. 104, 419-427. http://dx.doi.org/10.1016/j.agee.2004.01.044

Joseph, B. Patra, R. R., \& Lawrence, R. (2007). Characterization of plant growth promoting rhizobacteria associated with chickpea (Cicer arietinum L.). International Journal of Plant Production. 2, 141-152.

Juniper, S., \& Abbott, L. K. (2006). Soil salinity delays germination and limits growth of hyphae from propagules of arbuscular mycorrhizal fungi. Mycorrhizal. 6, 371-379. http://dx.doi.org/10.1007/s00572-006-0046-9

Khalid, A. Arshad, M., \& Zahir, Z. A. (2004). Screening plant growth promoting rhizobacteria for improving growth and yield of wheat. Journal of Applied Microbiology. 96(3), 473-480. http://dx.doi.org/10.1046/j.1365-2672.2003.02161.x

Kharwar, R. N. Mishra, A. Gond, S. K. Stierle, A., \& Stierle, D. (2011). Anticancer compounds derived from fungal endophytes: their importance and future challenges. Natural Product Reports. 28, 1208-1228. http://dx.doi.org/10.1039/c1np00008j

Kimmons, C. A. Gwinn, K. D., \& Bernard, E. C. (1990). Nematode reproduction on endophyte-infected and endophyte-free tall fescue. Plant disease. 74, 757-761. http://dx.doi.org/10.1094/PD-74-0757

Kogel, K. H. Franken, P., \& Hückelhoven, R. (2006). Endophyte or parasite - what decides. Current Opinion in Plant Biology. 9, 358-363. http://dx.doi.org/10.1016/j.pbi.2006.05.001

Kohn, L. M., \& Stasovski, E. (1990). The mycorrhizal status of plants at Alexandra Fiord, Ellesmere Island, Canada, a high Arctic site. Mycologia, 82, 23-35. http://dx.doi.org/10.2307/3759959

Kuldau, G., \& Bacon, C. (2008). Clavicipitaceous endophytes: their ability to enhance resistance of grasses to multiple stresses. Biological Control. 46, 57-71. http://dx.doi.org/10.1016/j.biocontrol.2008.01.023

Kusari, S. Lamshoft, M., \& Spiteller, M. (2009). Aspergillus fumigatus fresenius, an endophytic fungus from Juniperus communis L. Horstmann as a novel source of the anticancer 
pro-drug deoxypodophyllotoxin. Applied Microbiology. 107, 1364-5072. http://dx.doi.org/10.1111/j.1365-2672.2009.04285.x

Kusari, S., \& Spiteller, M. (2012b). Metabolomics of endophytic fungi producing associated plant secondary metabolites: progress, challenges and opportunities. In: U. Roessner (Ed), (pp. 241-266). Metabolomics, Rijeka, Croatia: InTech.

Lorito, M. Woo, S. L, D’Ambrosio, M. Harman, G. E. Hayes, C. K. Kubicek, C. P., \& Scala, F. (1996). Synergistic Interaction between Cell Wall Degrading Enzymes and Membrane Affecting Compounds. Molecular Plant-Microbe Interactions. 9, 206-213. http://dx.doi.org/10.1094/MPMI-9-0206

Lu, Z. Zhu, H. Fu, P. Wang, Y. Zhang, Z. Lin, H. Liu, P. Zhuang, Y. Hong, K., \& Zhu, W. (2010). Cytotoxic polyphenols from the marine-derived fungus Penicillium expansum. Journal of Natural Products. 73, 911-914. http://dx.doi.org/10.1021/np100059m

Lyons, P. C. Evans, J. J., \& Bacon, C. W. (1990). Effects of the fungal endophyte Acremonium coenophialum on nitrogen accumulation and metabolism in Tall Fescue. Plant Physiology. 92, 726-732. http://dx.doi.org/10.1104/pp.92.3.726

Macías-Rubalcava, M. L. Hernández-Bautista, B. E. Jiménez-Estrada, M. González, M. C. Glenn, A. E. Hanlin, R. T. Hernández-Ortega, S. Saucedo-Garcia, A. Muria-González, J. M. Anaya, A. L. (2008). Naphthoquinone spiroketal with allelochemical activity from the newly discovered endophytic fungus Edenia gomezpompae. Phytochemistry. 69, 1185-1196. http://dx.doi.org/10.1016/j.phytochem.2007.12.006

Madigen, O. (1999). Thermophilic and halophilic extremophiles. Current Opinion in Microbiology. 2, 265-269. http://dx.doi.org/10.1016/S1369-5274(99)80046-0

Malinowski, D. Leuchtmann, A. Schmidt, D. Nsberger, J. (1997). Growth and water status in meadow fescue (Festuca pratensis) is differently affected by its two natural endophytes. $\begin{array}{llrl}\text { Agronomy } & \text { Journal. } & \text { 673-678. }\end{array}$ http://dx.doi.org/10.2134/agronj1997.00021962008900040021x

Malinowski, D. P. Brauer, D. K., \& Belesky, D. P. (1999). Neotyphodium coenophialum-endophyte affects root morphology of tall fescue grown under phosphorus deficiency. Journal of Agronomy and Crop Science. 183, 53-60. http://dx.doi.org/10.1046/j.1439-037x.1999.00321.x

Malinowski, D. P., \& Belesky, D. P. (1999). Endophyte infection enhances the ability of tall fescue to utilize sparingly available phosphorus. Journal of Plant Nutrition. 22, 835-853. http://dx.doi.org/10.1080/01904169909365675

Malla, R. Prasad, R. Giang, P. H. Pokharel, U. Oelmueller, R. Varma, A. (2004). Characteristic features of symbiotic fungus Piriformospora indica. Endocytobiosis and Cell Research. 15, $579-600$.

Marulanda, A. Porcel, R. Barea, J., \& Azcón, R. (2007). Drought tolerance and antioxidant activities in lavender plants colonized by native drought-tolerant or drought- sensitive Glomus 
species. Microbial Ecology. 54, 543-552. http://dx.doi.org/10.1007/s00248-007-9237-y

Marvanova, L., \& Fisher, P. J. (1991). Fungal endophytes in submerged roots. In: B. Schulz, C. Boyle, T. Sieber (Eds.), Microbial Root Endophytes (pp. 179-190). Springer Berlin Heidelberg.

McKendrick, S. L. Leake, J. R., \& Read, D. J. (2000). Microbial Endophytes of Orchid Roots. In: B. Schulz, C. Boyle, T, Sieber (Eds.), Microbial Root Endophytes (pp. 153-177). Springer Berlin Heidelberg.

Meyer, S. L. F. Roberts, D. P. Chitwood, D. J. Carta, L. K. Lumsden, R. D., \& Mao, W. (2001). Application of Burkholderia cepacia and Trichoderma virens alone and in combinations against Meloidogyne incognita on bell pepper. Nematropica. 31, 75-86.

Moricca, S., \& Ragazzi, A. (2008). Fungal endophytes in Mediterranean oak forests: a lesson $\begin{array}{llll}\text { from Discula } & \text { quercinar } & \text { Phytopathology. } & 98,\end{array}$ http://dx.doi.org/10.1094/PHYTO-98-4-0380

Morse, L. J. Day, T. A. Faeth, \& S. H. (2002). Effect of Neotyphodium endophyte infection on growth and leaf gas exchange of Arizona fescue under contrasting water availability regimes. Environmental and Experimental Botany. 48, 257-268. http://dx.doi.org/10.1016/S0098-8472(02)00042-4

Munchbach, M. Nocker, A., \& Narberhaus, F. (1999). Multiple small heat shock proteins in rhizobia. Journal of Bacteriology. 181, 83-90.

Narisawa, K. Usuki, F., \& Hashiba, T. (2004). Control of Verticillium yellows in Chinese cabbage by the dark septate endophytic fungus LtVB3. Phytopathology. 94, 412-418. http://dx.doi.org/10.1094/PHYTO.2004.94.5.412

Neto, D. Carvalho, L. M. Cruz, C., \& Martin-Loucao, M. A. (2006). How do mycorrhizas affect $\mathrm{C}$ and $\mathrm{N}$ relationships in flooded Aster trifolium plants. Plant Soil. 279, 51-63. http://dx.doi.org/10.1007/s11104-005-6333-y

Newsham, K. K. (2011). A meta-analysis of plant responses to dark septate root endophytes. New Phytolologist. 190. 783-793. http://dx.doi.org/10.1111/j.1469-8137.2010.03611.x

Oelmuller, R. Sherameti, I. Tripathi, S., \& Varma, A. (2009). Piriformospora indica- a cultivable root endophyte with multiple biotechnological applications. Symbiosis. 49, 1-17. http://dx.doi.org/10.1007/s13199-009-0009-y

Pal, K. K. Tilak, K. V. B. R. Saxena, A. K. Dey, R., \& Singh, C. S. (2001). Supression of maize root disesase caused byMacrophomina phaseolina, Fusarium moniliforme and Fusarium graminearum by plant growth prmoting rhzobacteria. Microbiological Research. 156, 209-223. http://dx.doi.org/10.1078/0944-5013-00103

Park, J. H. Choi, G. J. Lee, H. B. Kim, K. M. Jung, H. S. Lee, S. W. Jang, K. S., \& Cho, K. Y. (2005). Griseofulvin from Xylaria sp. strain F0010, and endophytic fungus of Abies holophylla and its antifungal activity against plant pathogenic fungi. Journal Microbiology and Biotechnology. 15, 112-117. 
Patterson, C. G. Potter, D. A., \& Fanin, F. F. (1991). Feeding deterrence of alkaloids from endophyte-infected grasses to Japanese beetle grubs. Entomologia Experimentalis et Applicata. 61, 285-289. http://dx.doi.org/10.1111/j.1570-7458.1991.tb01561.x

Pham, G. H. Kumari, R. Singh, A. N. Sachdev, M. Prasad, R. Kaldorf, M. Buscot, F. Oelmüller, R. Peśkan, T. Weiss, M. Hampp, R., \& Varma, A. (2004). Axenic cultures of Piriformospora indica. In: A. Varma, L. Abbott, D. Werner, R. Hampp (Eds.), Plant Surface Microbiology (pp 593-616). Springer-Verlag, Germany.

Pimentel, M. R. Molina, G. Dionísio, A. P. Junior, M. R. M., \& Pastore, G. M. (2011). The Use of Endophytes to Obtain Bioactive Compounds and Their Application in Biotransformation Process. Biotechnology Research International. 1-11. http://dx.doi.org/10.4061/2011/576286

Prasad, R. Kamal, S. Sharma, P. K. Oelmueller, R., \& Varma, A. (2013). Root endophyte Piriformospora indica DSM 11827 alters plants morphology, enhances biomass and antioxidant activity of medicinal plant Bacopa monniera. Journal of Basic Microbiology. 53(12), 1016-1024. http://dx.doi.org/10.1002/jobm.201200367

Prasad, R. Pham, G. H. Kumari, R. Singh, A. Yadav, V. Sachdev, M. Peskan, T. Hehl, S. Oelmuller, R. Garg, A. P., \& Varma, A. (2005). Sebacinaceae: culturable mycorrhiza-like endosymbiotic fungi and their interaction with non-transformed and transformed roots. In: S. Declerck, D.G. Strullu, A. Fortin (Eds.), In vitro Culture of Mycorrhizas (pp. 291-312). Soil Biology Series, Springer-Verlag, Germany

Rai, M. Acharya, D., \& Singh, A. (2001). Positive growth responses of the medicinal plants Spilanthes calva and Withania somnifera to inoculation by Piriformospora indica in a field trial. Mycorrhiza. 11, 123-128. http://dx.doi.org/10.1007/s005720100115

Ramamoorthy, V. Viswanathan, R. Raguchander, T. Prakasam, V., \& Samiyappan, R. (2001). Induction of systemic resistance by plant growth promoting rhizobacteria in crop plants against $\begin{array}{lllll}\text { pests and Crop } \quad \text { diseases. } & \text { Protection. }\end{array}$ http://dx.doi.org/10.1016/S0261-2194(00)00056-9

Raps, A., \& Vidal, S. (1998). Indirect effects of an unspecialized endophytic fungus on specialized plant-herbivorous insect interactions. Oecologia. 114, 541-547. http://dx.doi.org/10.1007/s004420050478

Read, D. J., \& Haselwandter, K. (1981). Observation on the mycorrhizal status of some alpine $\begin{array}{lllll}\text { plant } \quad \text { communities. } & \text { New } & \text { 341-352. }\end{array}$ http://dx.doi.org/10.1111/j.1469-8137.1981.tb01729.x

Redman, R. S. Sheehan, K. B. Stout, R. G. Rodriguez, R. J., \& Henson, J. M. (2002). Thermotolerance conferred to plant host and fungal endophyte during mutualistic symbiosis. Science. 298 (5598). 1581.

Reininger, V., \& Sieber, T. N. (2012). Mycorrhizza reduces adverse effects of dark septate endophyte (DSE) on growth of conifers. Plos One. 7 (8): e42865. http://dx.doi.org/10.1371/journal.pone.0042865 


\section{$\triangle$ Macrothink}

Journal of Biology and Life Science ISSN 2157-6076 2014, Vol. 5, No. 2

Rodriguez, R. J. Henson, J. Van Volkenburgh, E. Hoy, M. Wright, L. Beckwith, F. Kim, Y., \& Redman, R. S. (2008). Stress tolerance in plants via habitat-adapted symbiosis. International Society of Microbial Ecology. 2, 404-416.

Rodriguez, R. J. Redman, R. S., \& Henson, J. M. (2004). The role of fungal symbioses in the adaptation of plants to high stress environments. Mitigation and Adaptation Strategies for Global Change. 9, 261-272. http://dx.doi.org/10.1023/B:MITI.0000029922.31110.97

Rodriguez, R., \& Redman, R. (2008). More than 400 million years of evolution and some plants still can't make it on their own: plant stress tolerance via fungal symbiosis. Journal of Experimental Botany. 59, 1109-1114. http://dx.doi.org/10.1093/jxb/erm342

Rubini, M. R. Silva-Ribeiro, R. T. Pomella, A. W. V. Maki, C. S. Arau' Jo, W. L. Dos Santos, D. R., \& Azevedo, J. L. (2005). Diversity of endophytic fungal community of cacao (Theobroma cacao L.) and biological control of Crinipellis perniciosa, causal agent of Witches' Broom Disease. International Journal of Biological Sciences. 1, 24-33. http://dx.doi.org/10.7150/ijbs.1.24

Ruiz-Lozano, J. M., \& Azcon, R. (2000). Symbiotic efficiency and infectivity of an autochthonous arbuscular mycorrhizal Glomus sp. from saline soils and Glomus deserticola under salinity. Mycorrhiza. 10, 137-143. http://dx.doi.org/10.1007/s005720000075

Rukachaisirikul, V. Sommart, U. Phongpaichit, S. Sakayaroj, J., \& Kirtikara, K. (2008). Metabolites from the endophytic fungus Phomopsis sp. PSU-D15. Phytochemistry. 69(3), 783-787. http://dx.doi.org/10.1016/j.phytochem.2007.09.006

Saharan, B. S., \& Nehra, V. (2011). Plant growth promoting Rhizobateria: A critical review. Life science and medicine research. 21, 1-30.

Saikkonen, K. Faeth, S. H. Helander, M., \& Sullivan, T. J. (1998). Fungal endophytes: A continuum of interactions with host plants. Annual Review of Ecology and Systematics. 29, 319-343. http://dx.doi.org/10.1146/annurev.ecolsys.29.1.319

Saikkonen, K. Ion, D., \& Gyllenberg, M. (2002). The persistence of vertically transmitted fungi in grass metapopulations. Proceedings of the Royal Society B: Biological Sciences. 269, 1397-1403. http://dx.doi.org/10.1098/rspb.2002.2006

Schulz, B. (2006). Mutualistic interactions with fungal root endophytes. In: B. Schulz, C. Boyle, T. Sieber (Eds.), Microbial root endophytes (pp. 261-280). Berlin, Germany: Springer-Verlag. http://dx.doi.org/10.1007/3-540-33526-9_15

Schulz, B. Boyle, C. Draeger, S. Römmert, A. K., \& Krohn, K. (2002). Endophytic fungi: a source of biologically active secondary metabolites. Mycological Research. 106, 996-1004. http://dx.doi.org/10.1017/S0953756202006342

Schulz, B. Rommert, A. K. Dammann, U. Aust, H. J., \& Strack, D. (1999). The endophyte-host interaction: a balanced antagonism. Mycological Research. 10, 1275-1283. http://dx.doi.org/10.1017/S0953756299008540 
Schulz, B. Sucker, J. Aust, H. J. Krohn, K. Ludewig, K., \& Jones, P. G. (1995). Biologically active secondary metabolites of endophytic Pezicula species. Mycological Research. 99, 1007-1015. http://dx.doi.org/10.1016/S0953-7562(09)80766-1

Schulz, B., \& Boyle, C. (2005). The endophytic continuum. Mycological Research. 109, 661-686. http://dx.doi.org/10.1017/S095375620500273X

Selosse, M. A. Dubois, M. P., \& Alvarez, N. (2009). Do Sebacinales commonly associate with plant roots as endophytes. Mycological Research. 113, 1062-1069. http://dx.doi.org/10.1016/j.mycres.2009.07.004

Serfling, A. Wirsel, S. G. R. Lind, V., \& Deising, H. B. (2007). Performance of the biocontrol fungus Piriformospora indica on wheat under greenhouse and field conditions. Phytopathology. 97, 523-531. http://dx.doi.org/10.1094/PHYTO-97-4-0523

Sheng, M. Tang, M. Chan, H. Yang, B. Zhang, F., \& Huang, Y. (2008). Influence of arbuscular mycorrhizae on photosynthesis and water status of maize plants under salt stress. Mycorrhiza. 18, 287-296. http://dx.doi.org/10.1007/s00572-008-0180-7

Shin, D. S. Oh, M. N. Yang, H. C., \& Oh, K. B. (2005). Biological characterization of periconicins, bioactive secondary metabolites, produced by Periconia sp. OBW-115. Journal of Microbiology and Biotechnology. 15, 216-220.

Shoebitz, M. Ribaudo, C. M. Pardo, M. A. Cantore, M. L. Ciampi, L., \& Curá, J. A. (2009). Plant growth promoting properties of a strain of Enterobacter ludwigii isolated from Lolium perenne rhizosphere. Soil Biologyand Biochemistry. 41, 1768-1774. http://dx.doi.org/10.1016/j.soilbio.2007.12.031

Srivastava, S. Yadav, A. Seem, K. Mishra, S. Chaudhary, V., \& Srivastava, C. S. (2008). Effect of high temperature on Pseudomonas putida NBRI0987 biofilm formation and expression of stress sigma factor RpoS. Current Microbiology. 56(4), 453-457. http://dx.doi.org/10.1007/s00284-008-9105-0

Strobel, G. A. Dirksie, E. Sears, J., \& Markworth, C. (2001). Volatile antimicrobials from Muscodor albus, a novel endophytic fungus. Microbiology. 147, 2943-2950.

Strobel, G. A. Kluck, K. Hess, W. M. Sears, J. Ezra, D., \& Vargas, P. N. (2007). Muscodor albus E-6, an endophyte of Guazuma ulmifolia, making volatile antibiotics: isolation, characterization and experimental establishment in the host plant. Microbiology. 153, 2613-2620. http://dx.doi.org/10.1099/mic.0.2007/008912-0

Strobel, G. A. Stierle, A. Stierle, D., \& Hess, W. M. (1993). Taxomyces andreanae a proposed new taxon for a bulbilliferous hyphomycete associated with Pacific yew. Mycotaxon. 47, 71-78.

Strobel, G. Knighton, B. Kluck, K. Ren, Y. Livinghouse, T. Griffen, M. Spakowicz, D., \& Sears, J. (2008). The production of myco- diesel hydrocarbons and their derivatives by the endophytic fungus Gliocladium roseum. Microbiology. 154, 3319-3328. http://dx.doi.org/10.1099/mic.0.2008/022186-0 


\section{Macrothink}

Journal of Biology and Life Science

ISSN 2157-6076

2014, Vol. 5, No. 2

Strobel, G. Yang, X. S. Sears, J. Kramer, R. Sidhu, R. S., \& Hess, W. M. (1996). Taxol from Pestalotiopsis microspora, an endophytic fungus of Taxus wallachiana. Microbiology. 142, 435-440. http://dx.doi.org/10.1099/13500872-142-2-435

Supothina, S. Isaka, M., \& Wongsa, P. (2007). Optimization of culture conditions for production of the anti-tubercular alkaloid hirsutellone A by Trichoderma gelatinosum BCC 7579. Letters in Applied Microbiology. 44(5), 531- 537. http://dx.doi.org/10.1111/j.1472-765X.2006.02098.x

Tan, R. X., \& Zhou, W. X. (2001). Endophytes: a rich source of functional metabolites. Natural Product Reports. 18, 448-459. http://dx.doi.org/10.1039/b100918o

Taylor, D. L. Bruns, T. D. Szaro, T. M., \& Hodges, S. A. (2003). Microbial Endophytes of Orchid Roots. In: B. Schulz, C. Boyle, T. Sieber (Eds.), Microbial Root Endophytes (pp. 153-177). Springer Berlin Heidelberg.

Tudzynski, B., \& Sharon, A. (2002). Biosynthesis, biological role and application of fungal phyto-hormones. In: H.D. Osiewacz (Ed) The mycota X. Industrial applications. (pp. 183-212). Berlin, Germany: Springer-Verlag. http://dx.doi.org/10.1007/978-3-662-10378-4_9

Unterseher, M., \& Schnittler, M. (2010). Species richness analysis and ITS rDNA phylogeny revealed the majority of cultivable foliar endophytes from beech (Fagus sylvatica). Fungal Ecology. 3, 366-378. http://dx.doi.org/10.1016/j.funeco.2010.03.001

Upson, R. Read, D. J., \& Newsham, K. K. (2009). Nitrogen form influences the response of Deschampsia antarctica to dark septate root endophytes. Mycorrhiza. 20(1), 1-11. http://dx.doi.org/10.1007/s00572-009-0260-3

Varma, A. Sherameti, I. Tripathi, S., \& Prasad, R. (2012). The symbiotic fungus Piriformospora indica: Review. In: B. Hock (Ed.), Fungal Associations, $2^{\text {nd }}$ edn, The Mycota IX (pp. 231-254). Springer-Verlag Berlin Heidelberg.

Varma, A. Verma, S. Sudha, Sahay, N. Butehorn, B., \& Franken, P. (1999). Piriformospora indica, a cultivable plant-growth-promoting root endophyte. Applied Environmental Microbiology. 65, 2741-2744.

Verma, S. Varma, A. Rexer, K. H. Hassel, A. Kost, G. Sarbhoy, A. Bisen, P. Butehorn, \& B. Franken, P. (1998). Piriformospora indica, gen. et sp. nov., a new root-colonizing fungus. Mycologia. 90, 896-903. http://dx.doi.org/10.2307/3761331

Vohnik, M. Albrechtova, J., \& Vosatka, M. (2005). The inoculation with Oidiodendron maius and Phialocephala fortinii alters phosphorus and nitrogen uptake, foliar $\mathrm{C}: \mathrm{N}$ ratio and root biomass distribution in Rhododendron cv. Azurro. Symbiosis. 40(2), 87-96.

Vu, T. Hauschild, R., \& Sikora, R. A. (2006). Fusarium oxysporum endophytes induced systemic resistance against Radopholus similis on banana. Nematology. 8, 847-852. http://dx.doi.org/10.1163/156854106779799259

Vujanovic, V. St-Arnaud, M. Barabe, D., \& Thibeautl, G. (2000). Microbial Endophytes of 


\section{$\Lambda$ Macrothink}

Journal of Biology and Life Science ISSN 2157-6076 2014, Vol. 5, No. 2

Orchid Roots. In: B. Schulz, C. Boyle, T. Sieber (Eds.), Microbial Root Endophytes, (pp. 153-177). Springer Berlin Heidelberg.

Wakelin, S. A. Warren, R. A. Harvey, P. R., \& Ryder, M. H. (2004). Phosphate solubilization by Penicillium spp. closely associated with wheat roots. Biology and Fertility of Soils. 40, 36-43. http://dx.doi.org/10.1007/s00374-004-0750-6

Waller, F. Achatz, B. Baltruschat, H. Fodor, J. Becker, K. Fischer, M. Heier, T. Huckelhoven, R. Neumann, C. Von Wettstein, D. Franken, P., \& Kogel, K. H. (2005). The endophytic fungus Piriformospora indica reprograms barley to salt-stress tolerance, disease resistance, and higher yield. Proceedings of the National Academy of Sciences, USA. 102(38), 13386-13391. http://dx.doi.org/10.1073/pnas.0504423102

Wang, C. J. K., \& Wilcox, H. E. (1985). New species of ectoendomycorrhizal and pseudomycorrhizal fungi: Phialophora finlandia, chloridium paucisporum and Phialocephala fortinii. Mycologia. 77, 951-958. http://dx.doi.org/10.2307/3793308

Wang, W. Vinocur, B., \& Altman, A. (2003). Plant responses to drought, salinity and extreme temperatures: toward genetic engineering for stress tolerance. Planta. 218, 1-14. http://dx.doi.org/10.1007/s00425-003-1105-5

Wang, W. X. Barak, T. Vinocur, B. Shoseyov, O., \& Altman, A. (2003). Abiotic resistance and chaperones: possible physiological role of SP1, a stable and stabilizing protein from Populus. In: I.K. Vasil (Ed.), Plant biotechnology 2000 and beyond (pp. 439-443). Dordrecht: Kluwer

Weber, R.W. Stenger, E. Meffert, A., \& Hahn, M. (2004b). Brefeldin A production by Phoma medicaginis in dead pre- colonized plant tissue: a strategy for habitat conquest. Mycological Research. 108, 662-671. http://dx.doi.org/10.1017/S0953756204000243

Weishampel, P., \& Bedford, B. (2006). Wetland dicots and monocots differ in colonization by arbuscular mycorrhizal fungi and dark septateendophytes. Mycorrhiza. 16, 495-502. http://dx.doi.org/10.1007/s00572-006-0064-7

West, C. P. (1994). Physiology and drought tolerance of endophyte- infected grasses. In: C.W. Bacon, \& J.F. White (Eds.), Biotechnology of endophytic fungi of grasses (pp. 87-99). CRC Press, Boca Raton FL.

Whipps, J. M. (2001). Microbial Interactions and Biocontrol in the rhizosphere. Journal of Experimental Botany. 52, 487-511. http://dx.doi.org/10.1093/jexbot/52.suppl_1.487

White, J. F., \& Torres, M. S. (2010). Is plant endophyte-mediated defensive mutualism the result of oxidative stress protection. Physiology Plant. 138, 440-446. http://dx.doi.org/10.1111/j.1399-3054.2009.01332.x

Wilcox, H. E., \& Wang, C. J. K. (1987b). Mycorrhizal and pathological associations of dematiaceous fungi in roots of 7-month-old tree seedlings. Candian Journal Forest Research. 17, 884-889. http://dx.doi.org/10.1139/x87-140

Wilson, D. (1995). Endophyte- the evolution of a term and clarification of its use and definition. 
Okios. 73, 274-276. http://dx.doi.org/10.2307/3545919

Woropong, J. Strobel, G. A. Ford, E. J. Li, J. Y. Baird, G., \& Hess, W. M. (2001). Muscodor albus anam.nov., an endophyte from Cinnamomum zeylanicum. Mycotaxon. 79, 67-79.

Wu, Q. S., \& Xia, R. X. (2006). Arbuscular mycorrhizal fungi influence growth, osmotic adjustment and photosynthesis of citrus under well watered and water stress conditions. Journal of Plant Physiology. 163(4), 417-425. http://dx.doi.org/10.1016/j.jplph.2005.04.024

Wu, S. C. Cao, Z. H. Li, Z. G. Cheung, K. C., \& Wong, M. H. (2005). Effects of biofertilizer containing $\mathrm{N}$ - fixer, $\mathrm{P}$ and $\mathrm{K}$ solublizers and $\mathrm{AM}$ fungi on maize growth: a greenhouse trial. Geoderma. 125, 155-166. http://dx.doi.org/10.1016/j.geoderma.2004.07.003

Xiao-Yan, S. Qing-Tao, S. Shu-Tao, X. Xiu-Lan, C. Cai-Yun, S., \& Yu-Zhong, Z. (2006). Broad-spectrum antimicrobial activity and high stability of Trichokonins from Trichoderma koningii SMF2 against plant pathogens. FEMS Microbiology. 260(1), 119-125. http://dx.doi.org/10.1111/j.1574-6968.2006.00316.x

Xing, X. K., \& Guo, S. X. (2011). Fungal endophyte communities in four Rhizophoraceae mangrove species on the south coast of China. Ecological Research. 26(2), 403-409. http://dx.doi.org/10.1007/s11284-010-0795-y

Yamato, M. Ikeda, S., \& Iwase, K. (2008). Community of arbuscular mycorrhizal fungi in coastal vegetation on Okinawa Island and effect of the isolated fungi on growth of sorghum under salt-treated conditions. Mycorrhiza. 18, 241-249. http://dx.doi.org/10.1007/s00572-008-0177-2

Yu, T. Nassuth, A., \& Petersen, R. L. (2001). Characterization of the interaction between the dark septate fungus Phialocephala fortinii and Asparagus officinalis roots. Canadian Journal Microbiology. 47, 741-753. http://dx.doi.org/10.1139/cjm-47-8-741

Zhang, H. W. Song, C. Y., \& Tan, R. X. (2006). Biology and chemistry of endophytes. Natural Products Report. 23, 753-771. http://dx.doi.org/10.1039/b609472b

Zikmundová, M. Drandarov, K. Bigler, L. Hesse, M., \& Werner, C. (2002). Biotransformation of 2 benzoxazolinone and 2- hydroxy-1,4-benzoxazin-3-one by endophytic fungi isolated from Aphe- landra tetragona. Applied and Environmental Microbiology. 68, 4863-4870. http://dx.doi.org/10.1128/AEM.68.10.4863-4870.2002

Zou, W. X., \& Tan, R. X. (1999). Advances in plant science. Beijing: China Higher Education Press. 2. 183-190.

Zuccaro, A. Basiewicz, M. Zurawska, M. Biedenkopf, D., \& Kogel, K. H. (2009). Karyotype analysis, genome organization, and stable genetic transformation of the root colonizing fungus Piriformospora indica. Fungal Genetics and Biology. 46, 542-550. http://dx.doi.org/10.1016/j.fgb.2009.03.009

Zuccaro, A. Lahramann, U. Idener, U. Langen, G. Pfiffi, S. Biedenkop, D. Wong, P. Samans, B. Grimm, C. Basiewicz, M. Murat, C. Martin, F., \& Kogel, K. H. (2011). Endophytic life 


\section{Macrothink}

strategies decoded by genome and transcriptome analyses of the mutualistic root symbiont Piriformospora indica. PLoS

http://dx.doi.org/10.1371/journal.ppat.1002290

\section{Copyright Disclaimer}

Copyright for this article is retained by the author(s), with first publication rights granted to the journal.

This is an open-access article distributed under the terms and conditions of the Creative Commons Attribution license (http://creativecommons.org/licenses/by/3.0/). 